Revista do Departamento de Geografia
Universidade de São Paulo
www.revistas.usp.br/rdg
Volume Especial (2016)
ISSN 2236-2878

\title{
IMPACTOS DA EXPANSÃO URBANA NA PORÇÃO NORTE DO MUNICÍPIO DE NOVA LIMA (MG) SOBRE O CLIMA
}

\author{
IMPACTS OF THE URBAN EXPANSION ON CLIMATE IN \\ THE NORTH PORTION OF NOVA LIMA (MG)
}

\author{
Lilian Aline Machado \\ Universidade Federal de Minas Gerais \\ lilian.aline.machado@hotmail.com \\ Wellington Lopes Assis \\ Universidade Federal de Minas Gerais \\ assisw@gmail.com
}

Resumo: O objetivo deste trabalho foi analisar as relações entre os componentes urbanos e geoecológicos em interação com a atmosfera na porção norte do município de Nova Lima (MG), que passa por um acelerado processo de expansão urbana e verticalização. Foram realizadas coletas de temperatura, umidade relativa do ar, direção e velocidade dos ventos em dois experimentos de campo. A análise rítmica foi empregada para a avaliação dos sistemas atmosféricos atuantes no período amostral. Os resultados atestaram a influência do processo de urbanização e verticalização sobre a camada laminar da atmosfera local. O atual uso e ocupação do solo potencializou o aquecimento atmosférico em determinados períodos do dia, interferindo na direção e velocidade dos ventos e diminuindo a umidade do ar. Foi observado que a topografia e morfologia locais assumem papel primário na dinâmica dos elementos climáticos, tendo seus efeitos influenciados ou potencializados pelo adensamento urbano.

Palavras-chave: Clima urbano; Subsistema termodinâmico; Verticalização; Impactos topoclimáticos.

\begin{abstract}
The aim of this study was to analyze the relationship between urban and geoecological components interacting with the atmosphere in the northern part of the city of Nova Lima $(M G)$. The region is passing through an accelerated process of urbanization and verticalization. Temperature data, relative humidity, direction and the speed of the winds were collected in two field experiments. The rhythmic analysis was used to characterize the atmospheric systems in the field experiments. The results showed the influence of urbanization and verticalization on the boundary layer of the local atmosphere. The current urban land cover enhanced the atmospheric heating in certain periods of the day, affecting the direction and speed of the winds and decreasing humidity. It was noted that the altitude and morphology are important elements in the dynamics of climatic local.
\end{abstract}

Keywords: Urban climate; Thermodynamic subsystem; Verticalization; Local climate impacts. 


\section{INTRODUÇÃO}

A ocupação urbana ao mesmo tempo em que implica em derivações no quadro ecológico, assume diferentes funções e feições da massa edificada ao longo do tempo em um processo evolutivo que é condição básica para que a cidade seja capaz de alterar as condições climáticas locais e adquirir características próprias de um "clima urbano" (MONTEIRO, 1990).

No cerne das alterações climáticas sobre as cidades estão as modificações no balanço de energia local induzidas pelas interações entre os componentes urbanos e a superfície. A morfologia e a geometria urbana, os materiais utilizados nas construções e suas respectivas propriedades térmicas, a poluição atmosférica e a proporção entre áreas verdes e construídas, são os principais fatores das alterações do balanço energético local (OKE,1978; MONTEIRO, 1990; LANDSBERG, 2006). Tais alterações repercutem na dinâmica de variação dos elementos climáticos, o que resulta, em certos casos, no desconforto termohígrico e em situações de insalubridade.

Monteiro (1976) propôs que o estudo do clima urbano fosse atrelado à percepção humana e, dessa forma, definiu subsistemas associados ao Sistema Clima Urbano (S.C.U.) denominados "canais de percepção do clima". Esses compreendem o subsistema termodinâmico, relacionado ao conforto térmico; o subsistema físico-químico, atrelado à qualidade do ar; e o subsistema hidromecânico, que diz respeito ao impacto meteórico.

O subsistema termodinâmico perfaz toda a estrutura do S.C.U., já que a energia provinda do Sol, insumo básico do clima, é constantemente transformada na cidade, implicando em fluxos induzidos de calor (MONTEIRO, 1976). Assim, a componente térmica está intrinsicamente relacionada às barométricas, de ventilação, condensação e precipitações restritas ao núcleo do S.C.U.

As alterações do campo térmico são emblemáticas quando se trata de clima urbano, já que afetam diretamente o conforto humano e se associam, de alguma forma, a todas as outras componentes climáticas. Oke (1978) atribui às transformações geradas pela ocupação urbana no balanço de energia a configuração de bolsões de ar mais aquecidos sobre as áreas urbanas, os quais são denominados de ilhas de calor. Assis (2010) observou o desenvolvimento de ilhas de calor no município de Belo Horizonte associadas com os locais mais adensados e impermeabilizados do município. O processo de arrefecimento térmico noturno no ambiente urbano é desacelerado em função da obstrução da abóbada celeste, que favorece a contínua troca de energia entre a massa edificada.

As áreas de vegetação no interior das cidades são importantes, pois elas, por um lado, agem na produção noturna de ar frio e fresco e, por outro, em locais muito arborizados, proporcionam equilíbrio térmico durante o dia, em função do sombreamento da superfície provocado pelo dossel arbóreo (BAUMÜLLER et al., 1997). Para áreas de vegetação densa pode-se, inclusive, considerar uma camada atmosférica de influência microclimática abaixo do dossel, a qual Oke (1978) denomina camada dos troncos (trunkspace), onde imperam os efeitos microclimáticos impostos pela cobertura das folhas. O esperado é que durante o dia a atmosfera sob a camada do dossel seja de temperatura mais fresca do que áreas abertas ou de adensamento urbano e durante a noite, o dossel arbóreo dificulte a perda de radiação para atmosfera mantendo o ar mais aquecido sob o dossel (OKE, 1978; BAUMÜLLER et al., 1997; MACHADO et al., 2014). Áreas verdes internas da cidade têm um efeito positivo sobre seu entorno imediato no aspecto microclimático, não se estendendo sobre a malha urbana os efeitos de parques e praças arborizadas. Ainda assim, a arborização das ruas pode trazer maior conforto climático ao pedestre e habitantes locais.

Os elementos urbanos são compostos por materiais de diferentes albedos, o que é um fator de interferência no balanço de radiação sobre áreas urbanas. O asfalto, por exemplo, apresenta um albedo que alcança até $20 \%$, enquanto em uma cobertura de grama atinge uma taxa de até $80 \%$ (BIAS et al., 2003). Dessa forma, a superfície de asfalto absorve mais radiação de ondas curtas do que uma superfície de grama, potencializando a emissão de ondas longas e o aquecimento atmosférico.

Se por um lado algumas superfícies urbanas são aptas a absorver mais radiação de ondas curtas e, portanto, emitir mais radiação de ondas longas, por outro, a menor umidade contida na superfície urbana devido à impermeabilização desta favorece as trocas de calor sensível em detrimento das de calor latente. As trocas de calor sensível são responsáveis pelo aquecimento atmosférico, enquanto as trocas de calor latente atuam na mudança de estado físico da água, auxiliando no resfriamento do ar. Neste aspecto, os materiais na superfície urbana influem não somente na absorção de energia e aquecimento atmosférico, como também na diminuição da água disponível para evaporação e propagação de calor sensível. 
Em ambientes verticalizados verifica-se o aumento da velocidade do ar na medida em que se distancia da superfície. Segundo Romero (2000, p. 51), "o movimento do ar no meio urbano está em relação direta com as massas edificadas, a forma destas, suas dimensões e sua justaposição". O escoamento atmosférico na baixa troposfera afeta diretamente os pedestres e as edificações, podendo aumentar ou diminuir as perdas de calor por advecção. Em locais cujos edifícios possuem o mesmo gabarito há uma tendência de transferência do fluxo de ventos do solo para as coberturas. Assim, a diversidade morfológica horizontal e vertical dos gabaritos pode favorecer a ventilação ao nível dos pedestres (DUARTE, SERRA, 2003; ROMERO, 2000).

Quando as edificações se dispõem no espaço de forma adjacente às ruas formam o que Nunez e Oke (1977) denominam de canyon urbano. No interior dos canyons urbanos o balanço de energia é regido pela sua geometria, que define a magnitude e o tempo dos processos envolvidos nas trocas de energia em cada componente do ambiente. A circulação atmosférica também é modificada de acordo com a geometria do canyon que pode favorecer o escoamento paralelo ou perpendicular às suas paredes. Neste último caso, pode haver o desenvolvimento de pequenos vórtices no interior do canyon, com circulação turbulenta do ar.

Considerando-se os possíveis impactos climáticos advindos da verticalização, surgiu a preocupação deste estudo quanto ao padrão de ocupação assumido na região norte do município de Nova Lima, compreendida pelos bairros Vila da Serra, Vale do Sereno, Piemonte, Jardinaves, Jardim das Mangabeiras e Jardim da Torre. Esses bairros, localizados no limite político-administrativo entre os municípios de Nova Lima e Belo Horizonte (MG) (Figura 1), vivem, atualmente, um processo de rápida ocupação, verticalização e adensamento urbano, permitido após sucessivas mudanças na legislação municipal de uso e ocupação do solo.

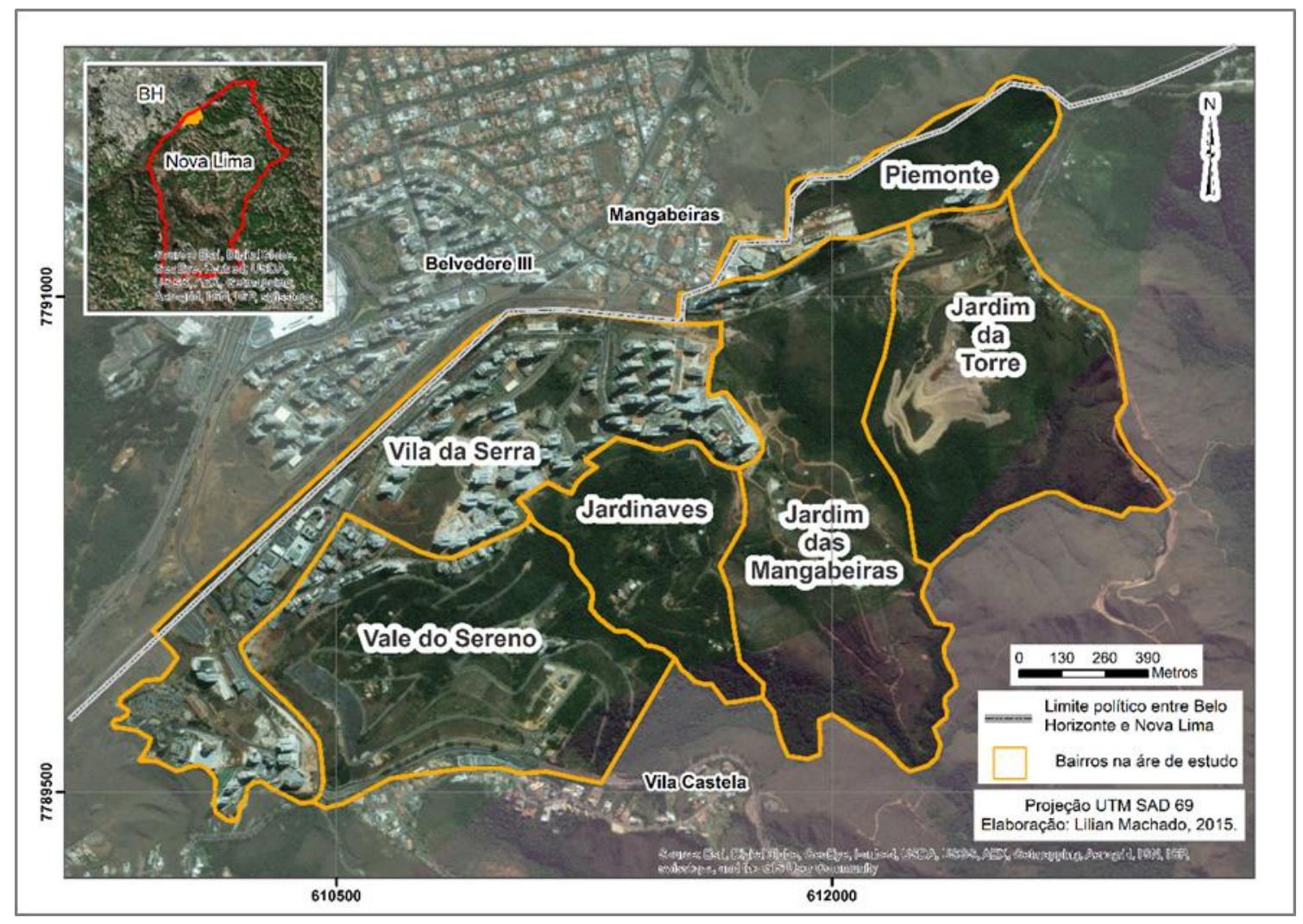

Figura 1: Localização dos bairros na área de estudo.

Em intensa verticalização, o Vila da Serra é ocupado por torres que beiram trinta pavimentos. Atualmente os bairros Vale do Sereno, Piemonte, Jardim da Torre, Jardim Mangabeiras e Jardinaves, são alvos do mesmo processo de expansão urbana e ocupação verticalizada. A grande oferta de lotes a baixo custo e em condições legais de ocupação, além da permissividade da legislação municipal quanto ao potencial construtivo na área, tornou a região atrativa ao mercado imobiliário. 
Contra todos os aspectos negativos de uma verticalização tão próxima a Serra do Curral, em área de cabeceira de rios e de vegetação nativa de campo rupestre, cerrado e mata atlântica, o poder público municipal não se opõe a essa ocupação, favorecendo a consolidação do processo de expansão da metrópole belo-horizontina (MENEGALE, 2002). O governo municipal estimula o crescimento da região, estabelecendo incentivos fiscais por meio de alíquotas inferiores às cobradas no município de Belo Horizonte ou a isenção fiscal por um período determinado, vantagens que se somam à localização dos bairros, próximos à zona sul da capital mineira (CRAVEIRO, 2005; MENEGALE, 2002).

O objetivo deste trabalho foi analisar as relações entre os componentes urbanos e geoecológicos em interação com a atmosfera nos bairros Vila da Serra, Vale do Sereno, Jardinaves, Jardim das Mangabeiras, Jardim das Torres e Piemonte. Foram diagnosticadas as respostas térmica, hígrica e anemométrica frente às características geoecológicas e de ocupação urbana dos bairros.

O conhecimento científico a respeito do comportamento dos elementos climáticos é oportuno e imprescindível aos planos de desenvolvimento econômico, os projetos de uso racional dos recursos naturais e os diagnósticos ambientais (ASSIS, 2010). Para além da importância do levantamento de possíveis impactos climáticos advindos da urbanização, é necessária a compreensão do clima urbano como um sistema, considerando em sua análise não somente as camadas de características superficiais sobrepostas, mas, principalmente, as conexões que se estabelecem entre elas. Dessa forma, é possível compreender os processos envolvidos na interação atmosfera-superfície, os quais devem fundamentar a visão prognóstica do planejador urbano a fim de se estabelecer bases para a ocupação do espaço de forma congruente entre a conservação da qualidade ambiental e do bem-estar humano.

\section{MATERIAIS E MÉTODOS}

Para atingir os objetivos desta pesquisa, foram realizados dois experimentos de campo com a finalidade de se levantar os dados necessários para o diagnóstico climático. O campo 1 aconteceu entre os dias 22 de agosto e 24 de setembro de 2015 e consistiu na coleta de dados horários de temperatura e umidade relativa do ar. O período de dados coletados de pouco mais de um mês serviu para avaliar o comportamento térmico e hígrico da região em termos médios e sob a atuação de diferentes sistemas atmosféricos.

Os registros de temperatura e umidade relativa do ar foram realizados por termo higrômetros dataloggers fabricados pela TFA Dostman / Wertheim, modelo 30.3015 (Figura 2a). Antes da realização dos experimentos de campo realizou-se as aferições dos aparelhos no intuito de que fossem verificadas eventuais falhas de funcionamento que pudessem inutilizar os dados coletos em campo. A confiabilidade dos equipamentos foi averiguada em duas etapas. Na primeira etapa todos os dataloggers foram numerados e em seguida colocados em um ambiente sem incidência direta de luz solar. A iluminação artificial permaneceu desligada durante a aferição. Os resultados mostraram que a máxima variação de temperatura e umidade relativa entre os termo-higrômetros dataloggers foi de $0,3^{\circ} \mathrm{C}$ e $2 \%$ respectivamente. Em relação ao termômetro convencional e ao termo-higrômetro de leitura direta, não foram registradas discrepâncias acima de $0,2^{\circ} \mathrm{C}$ e $1 \%$ respectivamente. Na segunda etapa aferiram-se os termo-higrômetros dataloggers do Instituto de Geociências (IGC/UFMG) com os pares psicrométricos do $5^{\circ}$ Distrito de Meteorologia do Instituto Nacional de Meteorologia ( $5^{\circ}$ DISME/INMET), sob a supervisão de um técnico desta Instituição. O coeficiente de correlação entre os aparelhos para a temperatura do ar foi de 0,95 (Figura. 3a), enquanto para a umidade relativa do ar foi de 0,91 (Figura 3b).

Os termo-higrômetros dataloggers foram instalados em abrigos meteorológicos de campo (Figura 2 b), confeccionados para realização de pesquisas acadêmicas pelo Prof. Wellington Lopes Assis (ASSIS, 2010) com base no modelo proposto pelo Prof. José Roberto Tarifa do Laboratório de Climatologia da Universidade de São Paulo. 


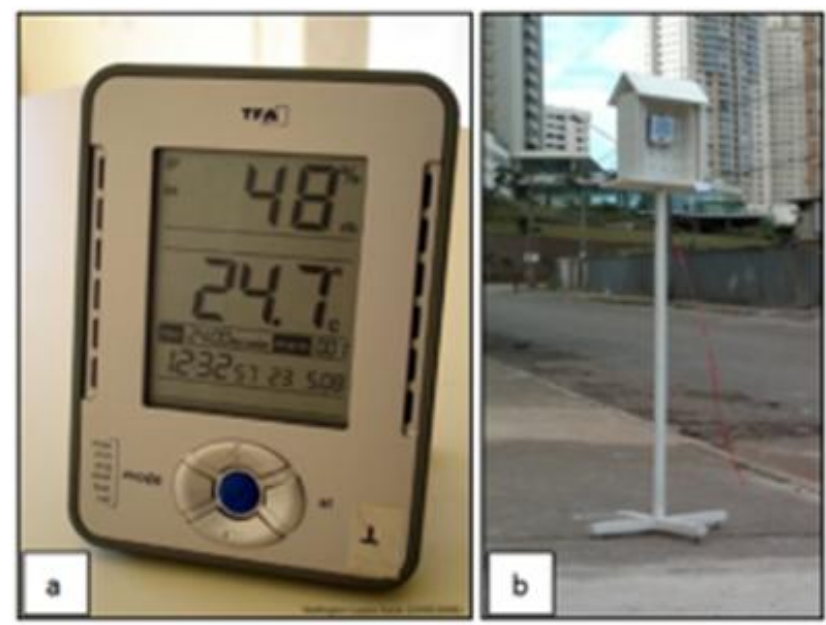

Figura 2: Instrumentos de registro em campo das variáveis meteorológicas; (a) Termo-higrômetro datalogger TFA; (b) Abrigo meteorológico de campo.

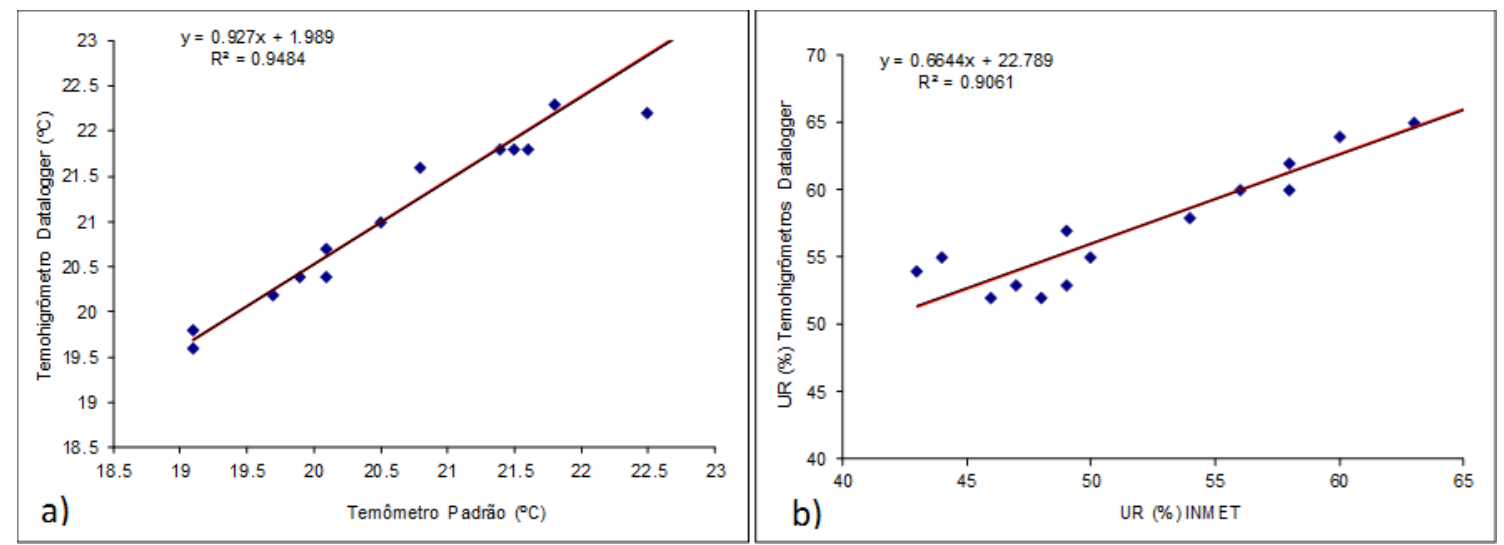

Figura 3: Gráfico de correlação entre os valores de temperatura do ar (a) e umidade relativa do ar (b) obtidos pelo termo-higrômetro datalogger e pelo termômetro de bulbo seco do $5^{\circ}$ DISME/INMET.

A coleta dos dados foi realizada em dez locais distribuídos na área de estudo (Figura 4). A escolha dos pontos amostrais foi feita considerando-se a multiplicidade de tipos de uso e ocupação do solo, a altitude, e a posição na vertente. Os abrigos foram instalados em áreas abertas de condomínios, edifícios empresariais e residências.

O segundo experimento de campo foi realizado no intuito de se obter dados complementares para a análise do clima urbano na área de estudo cujos os instrumentos a disposição para a realização da pesquisa e utilizados no campo 1 não são aptos a obter de forma automática. Os dados coletados no campo 2 consistem, além da temperatura e umidade relativa do ar, na velocidade e direção dos ventos e dados completares à análise como temperatura do solo, fluxo de veículos e pedestres, e nebulosidade. Os dados foram coletados em intervalos de 1 hora, iniciando-se às 13 horas do dia 25 de setembro e finalizando-se às 12 horas do dia 26 de setembro de 2015.

Para a coleta dos dados foi necessária a mobilização de uma equipe de campo, cujos integrantes se revezaram na coleta dos dados durante todo o período de realização do experimento. Dada a preocupação com a segurança dos voluntários e a dificuldade em acessar determinados locais durante a noite, optou-se pela exclusão de três pontos amostrais que compuseram o campo 1, sendo eles os pontos 8, 9 e 10. Os demais pontos, com exceção do ponto 1, precisaram ter os abrigos deslocados do interior dos condomínios e residências para a via pública em função da impossibilidade de adentrar os locais durante 24 horas. No entanto, mantiveram-se as mesmas características de uso e ocupação do solo locais apresentadas na Figura 4.

A coleta da temperatura e umidade relativa do ar foi realizada utilizando-se os mesmos instrumentos do campo 1. Já a direção e intensidade dos ventos foram obtidas com o auxílio de uma fita presa à haste dos 
abrigos e uma bússola para orientação. Os dados de intensidade do vento foram estimados por meio da escala Beaufort na medida em que se observava a movimentação da fita com o deslocamento do ar, a qual foi utilizada ainda para a observação da direção da qual partiam os ventos.

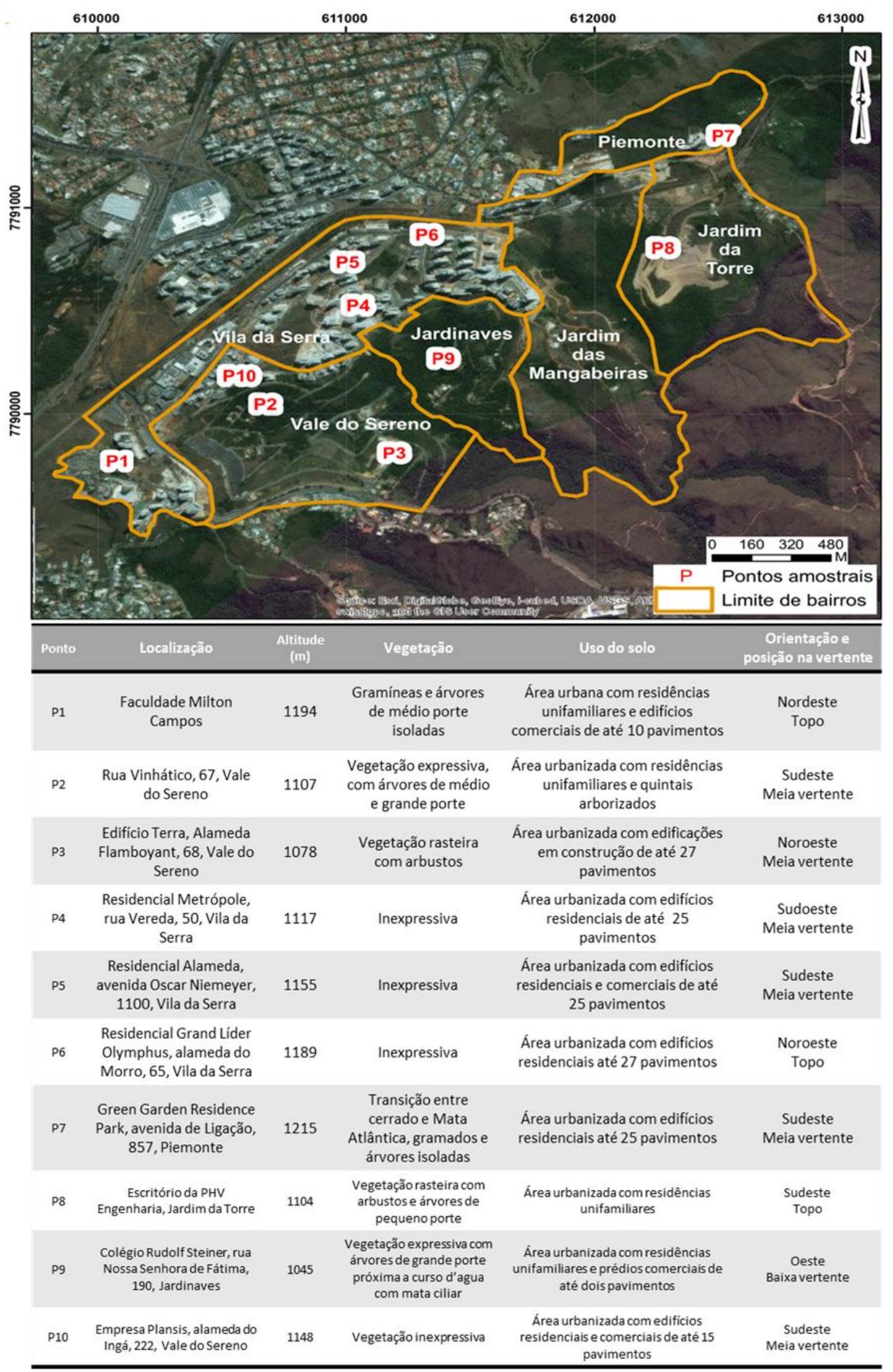

Figura 4: Localização dos pontos amostrais no campo 1. 
Foi realizada, no período de cinco dias anteriores e cinco dias posteriores à execução da coleta de dados do campo 1, a análise da situação sinótica e identificação dos sistemas atmosféricos atuantes na região, conforme metodologia proposta por Monteiro (1971). Para tanto, foram utilizados dados de pressão atmosférica, temperatura do ar (máxima, média e mínima), umidade relativa, pluviosidade diária total e direção e velocidade dos ventos obtidos por meio da estação meteorológica convencional do $5^{\circ}$ Distrito de Meteorologia ( $5^{\circ}$ DISME/INMET), localizada no bairro Lourdes, em Belo Horizonte. Esta etapa foi necessária já que o comportamento micro e topoclimático, aos quais se dirigem esta pesquisa, são indissociáveis das manifestações do clima em escala regional, na qual está incluída a atuação dos sistemas atmosféricos.

Para auxiliar na interpretação da dinâmica atmosférica e na identificação dos sistemas atuantes, foram utilizadas cartas sinóticas de altitude e superfície disponibilizadas pelo Centro de Previsão de Tempo e Clima (CPTEC/INPE) e imagens dos satélites GOES e METEOSAT nos horários sinóticos, sendo eles 00h00 min, $12 \mathrm{~h} 00 \mathrm{~min}$ e $18 \mathrm{~h} 00 \mathrm{~min}$ UTC (Universal Time Coordinated).

Foi elaborada uma base cartográfica com a função de espacializar os aspectos geoecológicos e de uso e ocupação do solo, além dos fatores de influência micro e topoclimática na área de estudo. Esta base incluiu: modelo digital de terreno; mapa de vegetação, cursos d'água, mapa de orientação das vertentes, mapa de radiação solar diária e de declividade, para avaliação das características geoecológicas locais; modelo em três dimensões das edificações presentes nos bairros e imagem de evolução da ocupação urbana para análise do uso e ocupação do solo. Os materiais cartográficos gerados serviram, ainda, na plotagem das variáveis meteorológicos obtidos em campo, as quais foram interpoladas e representadas cartograficamente.

Para análise da dinâmica de variação da temperatura do ar foi elaborada uma figura de iluminação solar no software Google Earth. Foi escolhida a imagem do dia oito de setembro de 2015 para gerar as imagens devido a esta ser a data mediana entre o início e o fim dos experimentos de campo. Foram elaborados, ainda, gráficos de obstrução da abóbada celeste e feito o cálculo do Fator de Visão do Céu (FVC) no software Google Sketchup dos pontos amostrais para auxiliar a análise da iluminação solar e a resposta térmica.

Após concluído o campo 1 , os dados obtidos de temperatura e umidade relativa do ar foram interpolados no software ArcGis 10.1, a fim de se obter uma representação espacial do comportamento térmico e hígrico médio na área de estudo. Foram calculados os valores médios das variáveis e esses foram inseridos em um arquivo de formato shapefile contendo os pontos amostrais do trabalho.

Foram realizados testes com cinco diferentes métodos de interpolação para se obter as melhores representações possíveis do comportamento atmosférico médio do local. Os interpoladores testados foram: Inverse Distance Weighting (IDW), Radial Basis Function (RBF), Local Polynomial Interpolation (LPI), Kriging e Kernel Smoothing. O modelo LPI apresentou os melhores resultados estatísticos e visuais para a interpolação dos dados de temperatura e umidade do ar. O erro médio produzido pelo modelo foi de $-0,051$ com coeficiente de correlação $\left(\mathrm{R}^{2}\right)$ de 0,93 .

A interpolação dos dados do campo 2 apresentou resultados não condizentes com as características geoecológicas das áreas centrais do espaço amostral devido à exclusão dos pontos 8 e 9 utilizados no Campo 1. Para corrigir o erro de distribuição dos pontos amostrais, foram sobrepostas as bases cartográficas de edificações, vegetação, topografia e direcionamento das vertentes sob a base de interpolação e corrigido o posicionamento das classes geradas pelo interpolador.

Para a análise das variáveis direção e velocidade dos ventos coletadas no Campo 2, foram elaborados gráficos de rosa dos ventos, e gráficos de frequência dos ventos por velocidade. Para a confecção dos gráficos foi utilizado o software livre WRPLOT View e o Excel.

\section{RESULTADOS E DISCUSSÕES}

Durante a realização dos experimentos de campo, entre os dias 22/08/2015 e 25/09/2015, as condições meteorológicas no Município de Belo Horizonte foram predominantemente estáveis, com ventos fracos e nuvens de baixo desenvolvimento vertical. Aconteceram duas exceções a este quadro (entre os dias 07-10/09 e 11-13/09), quando houve incursão de circulações sinóticas instáveis (linhas de instabilidade e sistemas frontais). O Anticiclone Subtropical do Atlântico Sul (ASAS) foi responsável por 79,8\% das condições meteorológicas, atuando no período de 17/08 a 06/09, e 15/09 (parte do dia) a 29/09 (Figura 5). Sob sua atuação as condições foram de estabilidade e temperaturas elevadas. As Linhas de Instabilidade (LI) 
foram responsáveis por 3,9\% das condições de tempo, atuando durante todo o dia 07/09 e parte do dia 08/09. Houve, ainda, a passagem de duas Frentes Frias (FF). A primeira atuou entre parte do dia 08/09 e parte do dia 10/09, sendo procedida pelo Anticiclone Subpolar do Atlântico Sul com características tropicalizadas, e a segunda permaneceu estacionada na área até parte do dia 13/09, quando passou a atuar o Anticiclone Subpolar do Atlântico Sul, que rapidamente adquiriu características tropicais. Durante a atuação desses sistemas foram observadas precipitações na região que atingiram acumulados diários de até $12 \mathrm{~mm}$.

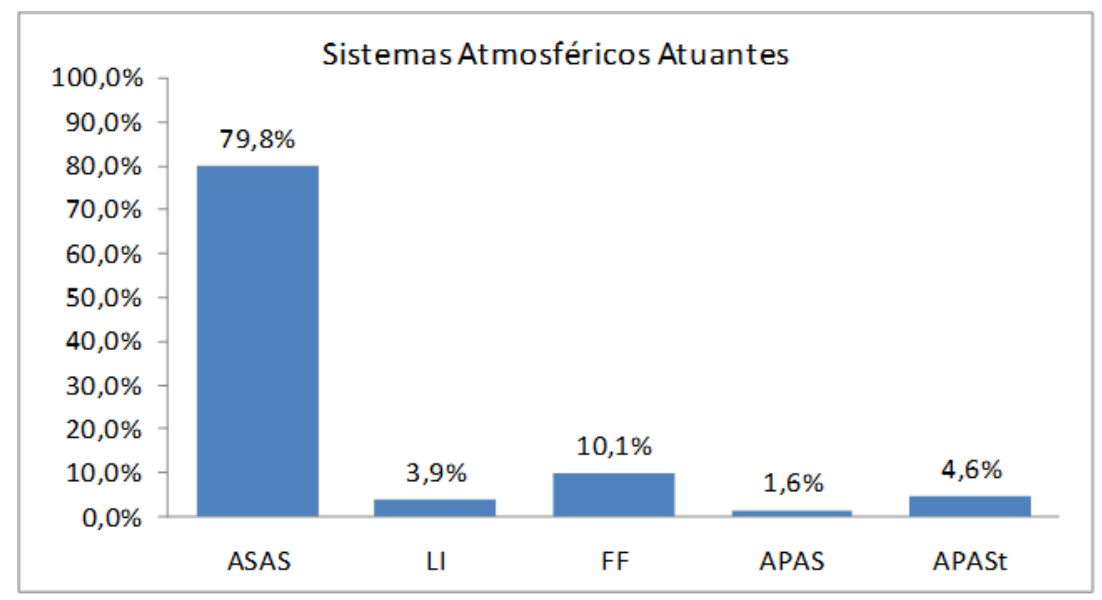

Figura 5: Percentual de participação dos sistemas atmosféricos na área de estudo no período de 22/08/2015 a $29 / 09 / 2015$.

Durante a participação de sistemas atmosféricos instáveis (entre os dias 7 e 10/09; 11 e 13/09), o comportamento térmico e hígrico entre os pontos amostrais da área de estudo tornou-se próximo de homogêneo (Figura 6), com variações térmicas espaciais médias que não ultrapassaram $1,5^{\circ} \mathrm{C}$. A nebulosidade em dias instáveis é um fator que favorece a homogeneização da temperatura do ar, minimizando a amplitude térmica e hígrica entre os pontos amostrais que se manifestam em função das diferenças geoecológicas e urbanas entre os locais.

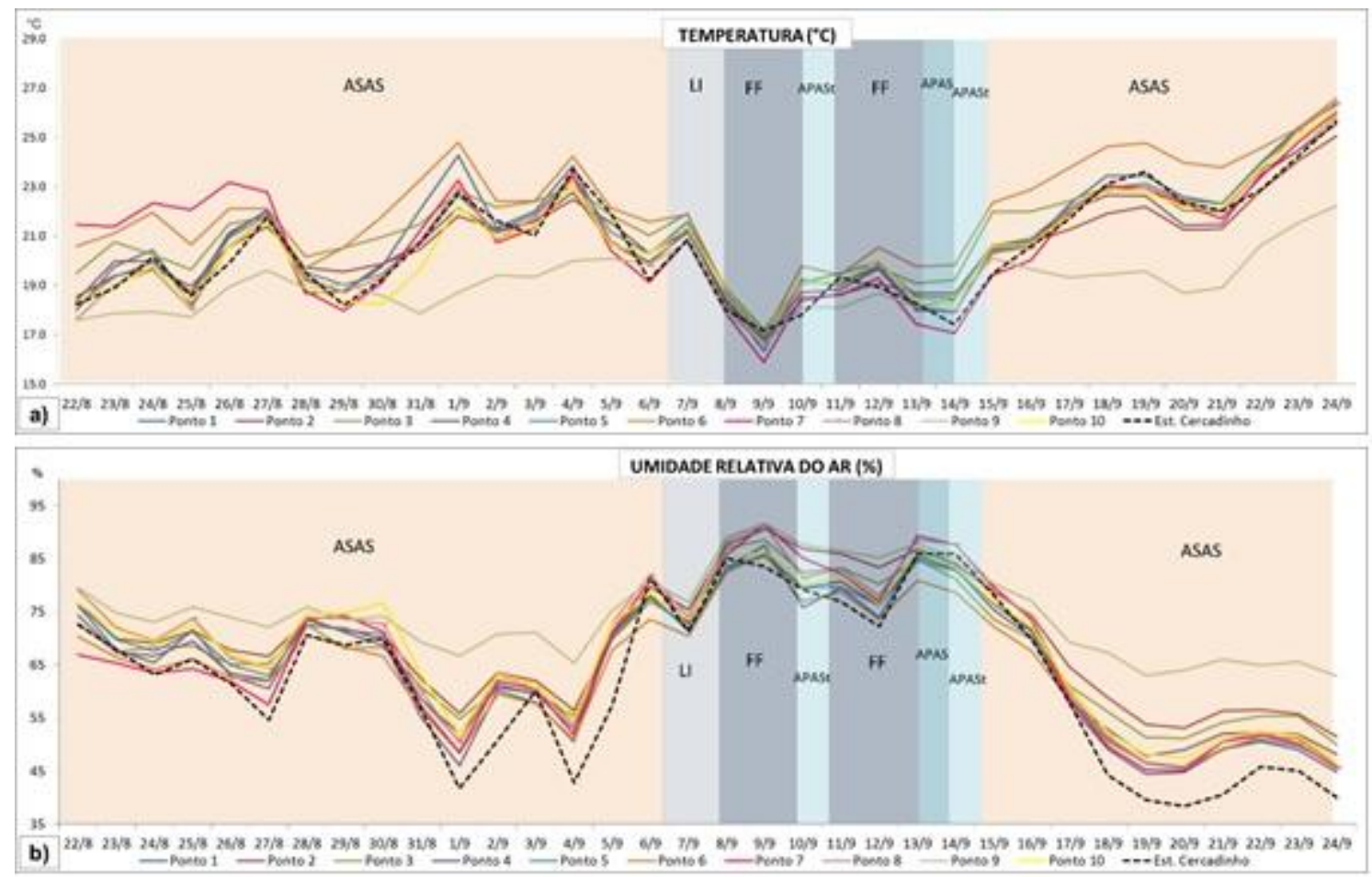

Figura 6: Variação térmica (a) e hígrica (b) entre os pontos amostrais de acordo com o sistema atmosférico atuante. 
Durante a atuação de sistemas sinóticos estáveis, a amplitude térmica entre os pontos amostrais foi favorecida. No entanto, sob o domínio do APAS e do APASt esta variação é reduzida em comparação com a atuação do ASAS. Isto porque os sistemas subpolares atuam após a passagem de sistemas instáveis que elevam a umidade do ar, diminuindo a amplitude térmica entre os pontos amostrais. Já sob a atuação do ASAS, a umidade do ar é gradualmente dissipada e o céu predominantemente limpo favorece as amplitudes térmicas, que, em média, ultrapassam $4^{\circ} \mathrm{C}$.

O período de realização dos experimentos de campo compreendeu temperaturas acima da média se comparadas os dados históricos da região. $\mathrm{O}$ mês de agosto apresentou média de temperatura de $22,0^{\circ} \mathrm{C}, 3^{\circ} \mathrm{C}$ a mais do que o registrado nas normais climatológicas para o mês no município de Belo Horizonte. Em setembro a média da temperatura foi de $25,5^{\circ} \mathrm{C}$, quando o esperado, segundo as normais climatológicas de 1961 a 1990 é de $21^{\circ} \mathrm{C}$.

As temperaturas acima da média se relacionam com a persistência do fenômeno El Niño-Oscilação Sul (ENOS) na região equatorial do Pacífico. O fenômeno teve início entre o fim de março e o início de abril do ano de 2014. A anomalia positiva da TSM sobre o oceano Pacífico Equatorial atingiu no mês de setembro valores acima dos $4^{\circ} \mathrm{C}$ e o Índice de Oscilação Sul registrou valores negativos chegando a $-1,6^{\circ} \mathrm{C}$ no mês de setembro (CPTEC, 2015). As temperaturas médias na região Sudeste do Brasil apresentaram valores acima da média climatológica, anomalia favorecida pela permanência do ASAS sobre o continente proporcionando baixa nebulosidade e aquecimento pronunciado da superfície continental.

Sob estas condições atmosféricas regionais, em que se destaca a predominância do ASAS atuando em 79,8\% do período de realização dos campos, os pontos 2 e 9 apresentaram as menores médias térmicas $\left(20,5^{\circ} \mathrm{C}\right.$ e $19,1^{\circ} \mathrm{C}$ no campo $1 ; 25,7^{\circ} \mathrm{C}$ no campo 2$)$, bem como os maiores valores médios da umidade relativa do ar em ambos os campos (70 e 75\% no campo 1 e $54 \%$ no campo 2). Os pontos estavam localizados em vertentes bem arborizadas, voltadas para o quadrante sul, com residências unifamiliares e construções comerciais esparsas de um pavimento. O P9 estava em ambiente de fundo de vale, próximo a um córrego. O direcionamento das vertentes, assim como a cobertura vegetal arbórea, desfavorece o ganho térmico em função do bloqueio que provoca à iluminação solar direta da superfície (Figura 7). Como resultado, observaram-se temperaturas mais baixas que condicionaram taxas de umidade do ar mais elevadas do que nos demais pontos. $\mathrm{O}$ efeito de atenuação média sobre a temperatura máxima nesses locais foi maior do que sobre a mínima. A diferença entre a maior e menor máxima foi de $8,9^{\circ} \mathrm{C}$, enquanto entre as mínimas foi de $3,9^{\circ} \mathrm{C}$ no campo 1 . Já no campo 2 , a amplitude entre as máximas foi de $6,6^{\circ} \mathrm{C}$, e entre as mínimas foi de $1,2^{\circ} \mathrm{C}$.

O P6 foi o mais quente em ambos os campos $\left(22,1^{\circ} \mathrm{C}\right.$ no campo 1 e $28,3^{\circ} \mathrm{C}$ no campo 2$)$, bem como o mais seco (64\% de umidade relativa do ar no campo 1 e $46 \%$ no campo 2). Sua localização no topo de uma vertente voltada para noroeste cercada por edificações de até 27 pavimentos favoreceu a incidência de radiação solar no local, sobretudo no período da tarde, elevando as temperaturas. No campo 2, os locais situados em áreas adensadas também apresentaram média elevada da temperatura ( $\mathrm{P} 4$ e 5), em função da absorção e emitância de calor pelos elementos urbanos $\left(14,3^{\circ} \mathrm{C}\right.$ no campo 1 e $21,2^{\circ} \mathrm{C}$ no campo 2$)$.

O P3 foi o segundo mais quente no campo $1\left(21,3^{\circ} \mathrm{C}\right)$ e esteve entre os mais quentes no campo 2 $\left(27,6^{\circ} \mathrm{C}\right)$. O entorno do local de instalação do abrigo meteorológico apresenta vegetação aberta em uma vertente exposta a iluminação solar. Sua urbanização e adensamento podem elevar as temperaturas mínima e máxima em determinados períodos do dia na região.

O mínimo de umidade relativa do ar observado durante o campo 1 foi de $15 \%$ (P1 no dia 19/09 às 13h). Os pontos 2, 3, 4, 6 e 10 apresentaram valores mínimos de $17 \%$ e $18 \%$ que também foram observados no dia 19/09. Os níveis críticos de umidade estão associados à atuação prolongada do Anticiclone Subtropical do Atlântico Sul. Em dias secos, mesmo os pontos arborizados e próximos a fontes de umidade apresentam índices de UR baixos. No entanto, a média diária da umidade nessas áreas (P2 e P9) se manteve acima dos $60 \%$ no campo 1, atingindo o nível recomendado para a salubridade, em contrapartida aos demais. No campo 2, o P2 teve média hígrica de 54\%, sendo a maior média dentre os demais.

No que diz respeito ao comportamento espacial da temperatura média na área de estudo, as áreas de fundo de vale foram as mais frescas, já que essas possuem cobertura de mata ciliar em estágio inicial e médio de regeneração, reduzindo a insolação no local, características que favorecem o acúmulo de umidade nessas áreas (Figura 8). 

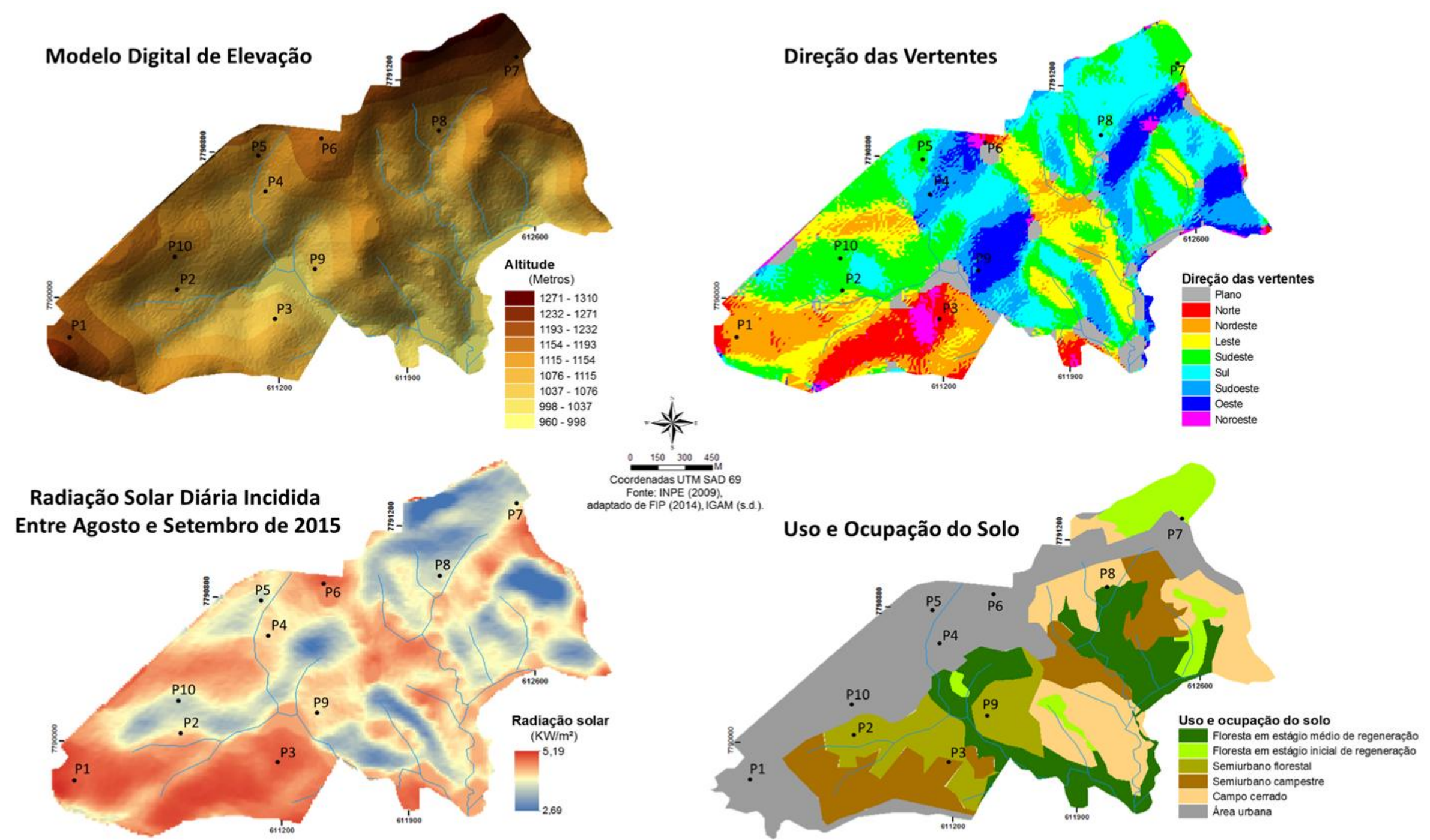

Figura 7: (a) Modelo digital de elevação, (b) direção das vertentes, (c) radiação solar diária registrada entre agosto e setembro de 2015 e (d) uso e ocupação do solo na área de estudo. 

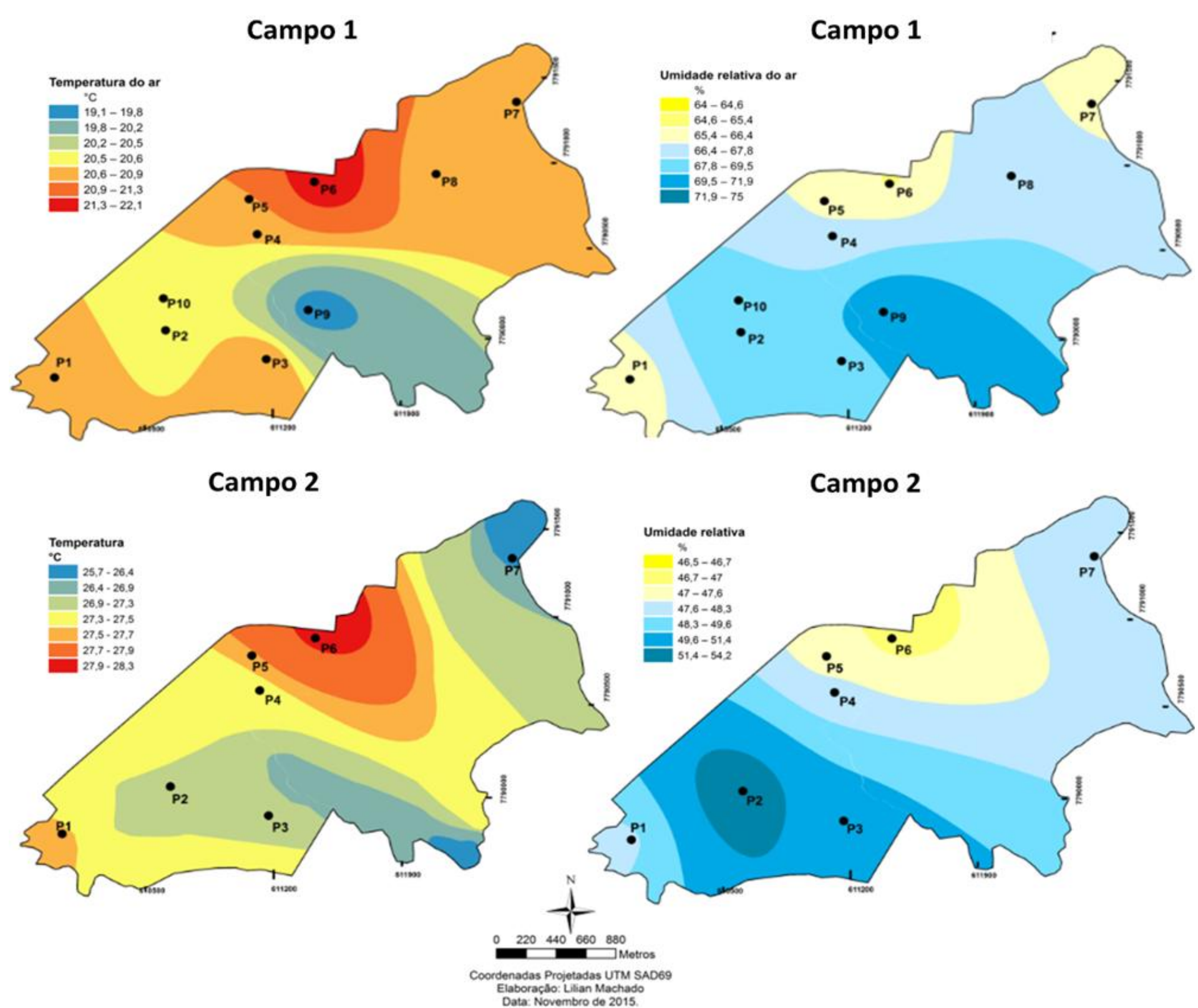

Figura 8: Distribuição espacial dos dados de temperatura e umidade relativa do ar coletados - Campos 1 e 2. 
É notável uma área central no bairro Vila da Serra mais aquecida e seca, no entorno do P6 (Figura 8). No local a boa iluminação solar direta ao longo do dia, a vegetação inexpressiva, a impermeabilização do solo e a concentração de edificações de até 27 pavimentos potencializam o aquecimento atmosférico. A maior frequência de calmarias também é um fator que favorece o aquecimento atmosférico na área, já que o transporte de calor para outros locais é reduzido (Figura 8). Além dele, o entorno dos pontos 3, 4 e 5 apresentaram um núcleo de aquecimento que perdura, com exceção do P3, durante a noite. Este último apresenta um desvio padrão de temperatura elevado, o que indica ser uma área onde há fácil absorção de calor, bem como acelerada dissipação. Os locais mais adensados e urbanizados, referentes aos pontos 4, 5 e 6 não apresentam desvio padrão mais baixo, já que a verticalização funciona como um fator de desaceleração da perda de calor no período noturno.

Os pontos 1, 5 e 7 apresentaram as maiores velocidades dos ventos, atingindo até $5,7 \mathrm{~m} / \mathrm{s}$. A frequência de calmarias nesses locais é mais baixa do que nos demais (Figura 9), sobretudo no P1 que apresentou frequência de $8,7 \%$ e 56,5\% de ventos na faixa de 3,6 a 5,7 m/s (Figura 9).
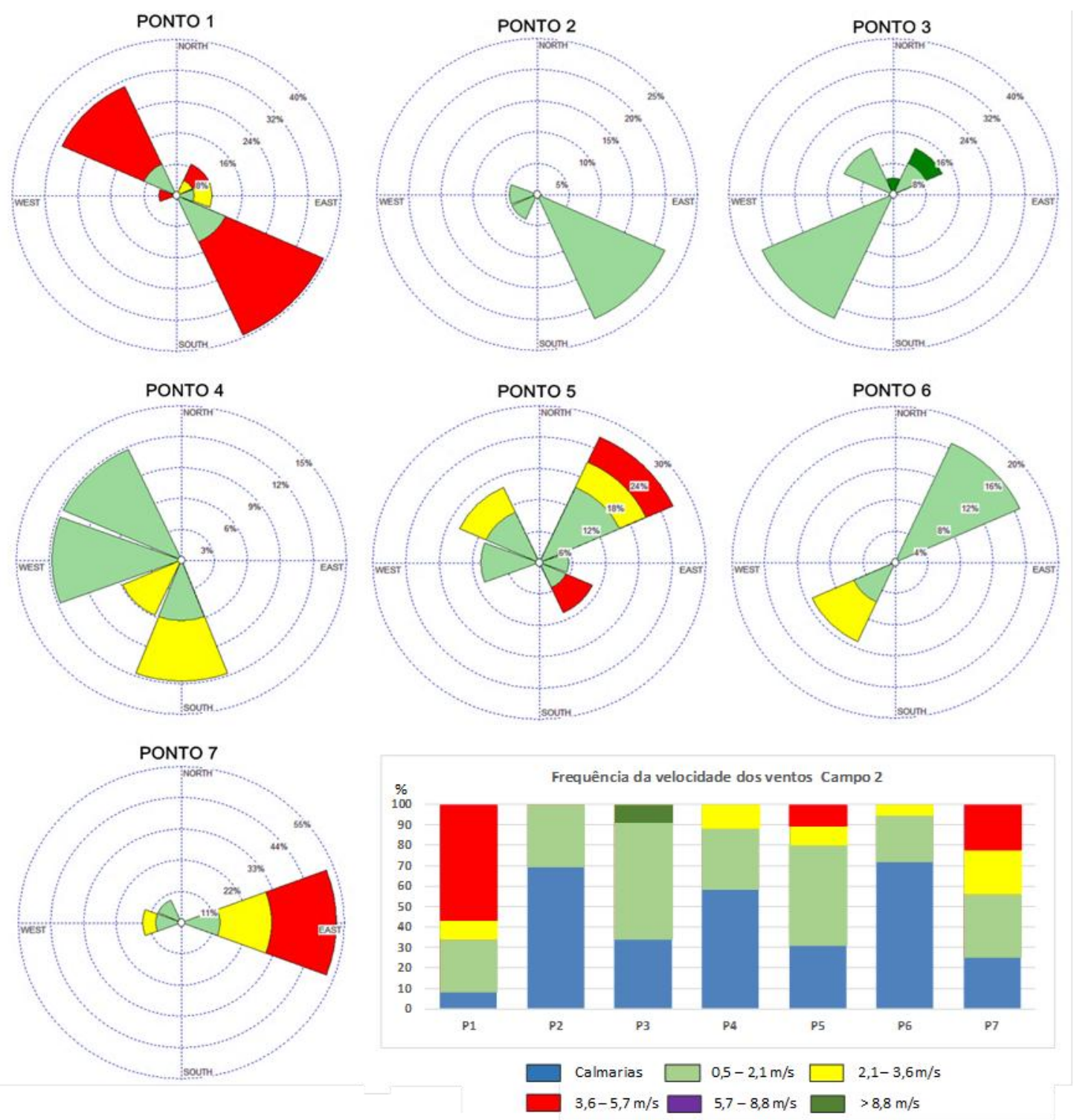

Figura 9: Rosa dos ventos - Campo 2. Elaboração: Lilian Machado, 2016.

No P5 a aceleração dos ventos parece estar ligada ao fluxo intenso de veículos em determinados horários e ao alinhamento das edificações no local que, formando uma espécie de cânion urbano, tende a canalizar os ventos. Já nos Pontos 1 e 7 a posição da vertente favorece o deslocamento do ar, bem como a dinâmica térmica diária influencia o desenvolvimento de brisas vale-montanha na região. Essa última fica 
visível nas rosas dos ventos nas quais os principais vetores se encontram em posições geográficas opostas (Figura 9).

O P2 apresentou a menor média de intensidade dos ventos e a segunda maior frequência de calmarias $(69,6 \%)$, devido à barreira que a arborização consiste à passagem dos ventos próximos à superfície. Os pontos 4.1 e 5.1, diferente dos demais, apresentaram direções variadas dos ventos (Figura 9). Estas características estão relacionadas ao efeito de turbulência que a verticalização das edificações provoca na camada atmosférica de cobertura urbana (UCL).

Ao longo do dia, o perfil de aquecimento e resfriamento dos pontos amostrais se relaciona com a geomorfologia local. Durante a manhã e a tarde, a direção das vertentes é um forte fator de influência sobre a variação da térmica e hígrica, enquanto a noite, a morfologia do terreno dita a dinâmica topoclimática.

No início da manhã, as vertentes voltadas para o quadrante leste e os topos são os primeiros locais a receberem iluminação solar direta (Figura 10). Dessa forma, a porção leste da área de estudo, bem como os topos onde estavam instalados os abrigos $1,6 \mathrm{e}$ 7, foram as áreas mais aquecidas neste período (Figura 11). As médias máximas registradas foram de $22,2^{\circ} \mathrm{C}$ (P5 no campo 1) e $28,9^{\circ} \mathrm{C}$ (P6 no campo 2). Esses também foram os locais de atmosfera mais seca, em função das temperaturas pronunciadas. As menores médias da umidade relativa do ar foram de $65 \%$ no campo 1 (P5) e $50 \%$ no campo 2 (P6). Nesses locais, a impermeabilização da superfície e a baixa arborização diminui o aporte de umidade à atmosfera.
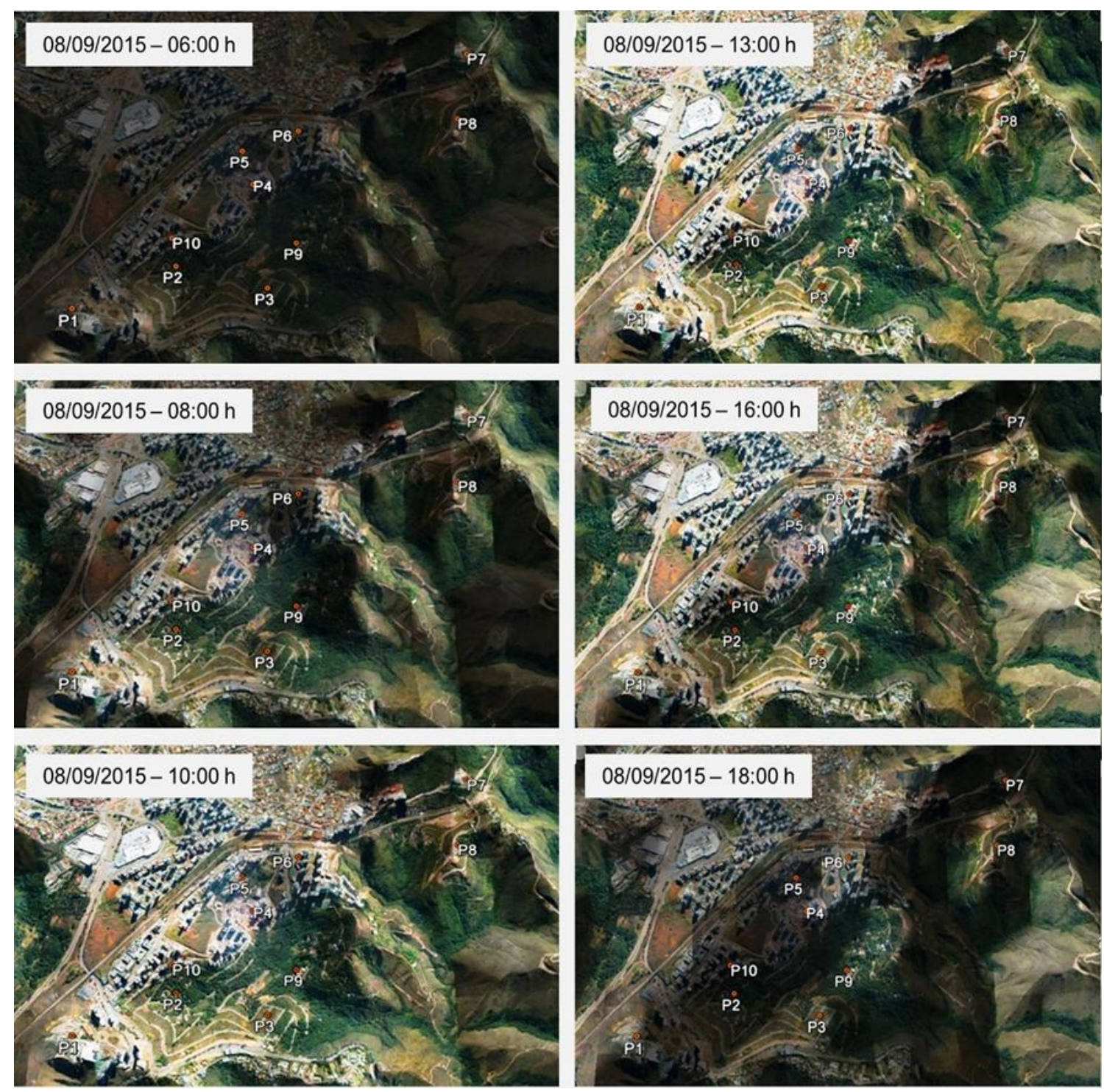

Figura 10: Iluminação solar no dia 08/09/2015 na área de estudo. Elaboração: Lilian Machado, 2016. Imagem do Google Earth. 
Em contrapartida, as áreas de fundo de vale e vertentes voltadas para o quadrante oeste foram as mais resfriadas, em função da insolação tardia durante a manhã (Figura 10). O P9, no campo 1, registrou a menor média da temperatura do ar $\left(19,9^{\circ} \mathrm{C}\right)$, enquanto no campo 2 , o $\mathrm{P} 2$ registrou a menor temperatura $\left(26^{\circ} \mathrm{C}\right)$. Nesses ambientes, a presença da vegetação de porte arbóreo potencializa o resfriamento abaixo da camada do dossel em função da predominância, neste nível atmosférico, da radiação difusa.

Durante a tarde o entorno do P3 se configura em um local de aquecimento pronunciado, assim como acontece no P6. O P3, localizado em uma vertente voltada para norte, recebe radiação solar direta até o fim do dia. A vegetação de gramíneas e arbustos não oferece bloqueio à radiação solar direta na atmosfera próxima a superfície, bem como não é fonte hígrica eficiente, potencializando os ganhos térmicos ao longo da tarde e reduzindo a umidade do ar. O P6 apresentou média térmica de $30,3^{\circ} \mathrm{C}$ e $43 \%$ de umidade relativa do ar neste período no campo 1 enquanto o $\mathrm{P} 3$ registrou $28,5^{\circ} \mathrm{C}$ de temperatura média e $47 \%$ de umidade relativa. No campo 2 , foram observados $36,2^{\circ} \mathrm{C}$ no $\mathrm{P} 3$ e $35,5^{\circ} \mathrm{C}$ no $\mathrm{P} 6$ e $27 \%$ de umidade relativa em ambos os pontos.

As vertentes a leste da área de estudo, em sua maioria voltadas para o quadrante leste, foram sombreadas no período da tarde anteriormente aos demais pontos, por volta das 15 horas (Figura 10). Dessa forma, estes foram os locais mais frios no período. A baixa temperatura média do $\mathrm{P} 7\left(23,9^{\circ} \mathrm{C}\right.$ no campo $1 \mathrm{e}$ $31^{\circ} \mathrm{C}$ no campo 2) superou inclusive os pontos arborizados e localizados em fundos de vale, como os pontos $2\left(25,5^{\circ} \mathrm{C}\right.$ no campo 1 e $32,2^{\circ} \mathrm{C}$ no campo 2$)$ e $9\left(24,6^{\circ} \mathrm{C}\right.$ no campo 1$)$. Esta foi a área mais úmida durante a tarde (Figura 11), assim como os locais em fundo de vale e áreas arborizadas.

No período noturno as vertentes a leste e nordeste da área de estudo apresentaram comportamento oposto ao observado durante a tarde, quando estavam mais resfriadas que as demais áreas. Durante a noite o arrefecimento térmico torna o ar mais denso, o qual assume, então, movimento descendente dos topos para os fundos de vale. Dessa forma, o ar resfriado é transportado para as áreas mais baixas, permanecendo os topos e meias vertentes mais aquecidos (Figura 11). Vale lembrar que as vertentes leste e nordeste apresentam um divisor de águas entre a microbacia do córrego Estrangulado e a microbacia do córrego da Torre, com desníveis de terreno acentuados (Figura 7). Assim, durante a noite o transporte de ar frio nessa região pode ser potencializado pelas características do terreno, mantendo os topos e meias vertentes da região mais aquecidas com relação as demais áreas.

Era esperado que nos locais arborizados a perda de calor na noite fosse reduzida em relação aos demais locais, dada a obstrução da abóbada celeste em que consiste a camada do dossel. No entanto, a arborização densa está presente em áreas de fundo de vale para onde escoa o ar resfriado no período noturno, tornando-as as áreas mais frias do período (Figura 11). O P9 apresentou a menor mínima $\left(12,8^{\circ} \mathrm{C}\right.$ no dia $01 / 09$ à $00 \mathrm{~h})$ e máxima $\left(22,1^{\circ} \mathrm{C}\right.$ no dia $24 / 09$ às $\left.19 \mathrm{~h}\right)$, o que condiz com o fluxo de ventos frios para o fundo do vale no início da noite. O P6, embora não tenha sido o mais quente do período noturno, apresentou as maiores temperaturas máxima $\left(28,5^{\circ} \mathrm{C}\right.$ no dia $24 / 09$ às $\left.19 \mathrm{~h}\right)$ e mínima absolutas $\left(15,9^{\circ} \mathrm{C}\right.$ no dia $09 / 09$ das 21hàs00h), influência de sua posição na vertente e do adensamento local.

À noite, os pontos de maior FVC (Figura 12), como o P4, P5 e P6 apresentaram perda mais lenta da temperatura do ar, em função da obstrução da abóbada celeste e da troca de energia radiativa de ondas longas entre os elementos urbanos. Já o P3, se resfriou rapidamente no início da noite dada as características locais de abóbada celeste livre de obstruções e a vegetação rasteira.

Durante a madrugada as tendências observadas à noite se mantiveram. Novamente foi observado que as áreas mais adensadas e verticalizadas têm efeito sobre a manutenção de calor na atmosfera durante a noite e madrugada, assim como áreas de topo. O efeito dos ventos catabáticos no transporte de ar frio para os fundos de vale manteve aquecidas as áreas de topo, sobretudo do entorno dos pontos 6 e 7, bem como a obstrução da abóbada celeste tornou o arrefecimento térmico nos pontos 4 e 5 reduzido (Figura 11). As áreas ao redor do $\mathrm{P} 3$, de FVC alto e de vegetação rasteira, apresentaram tendência a perda de temperatura acentuada. 

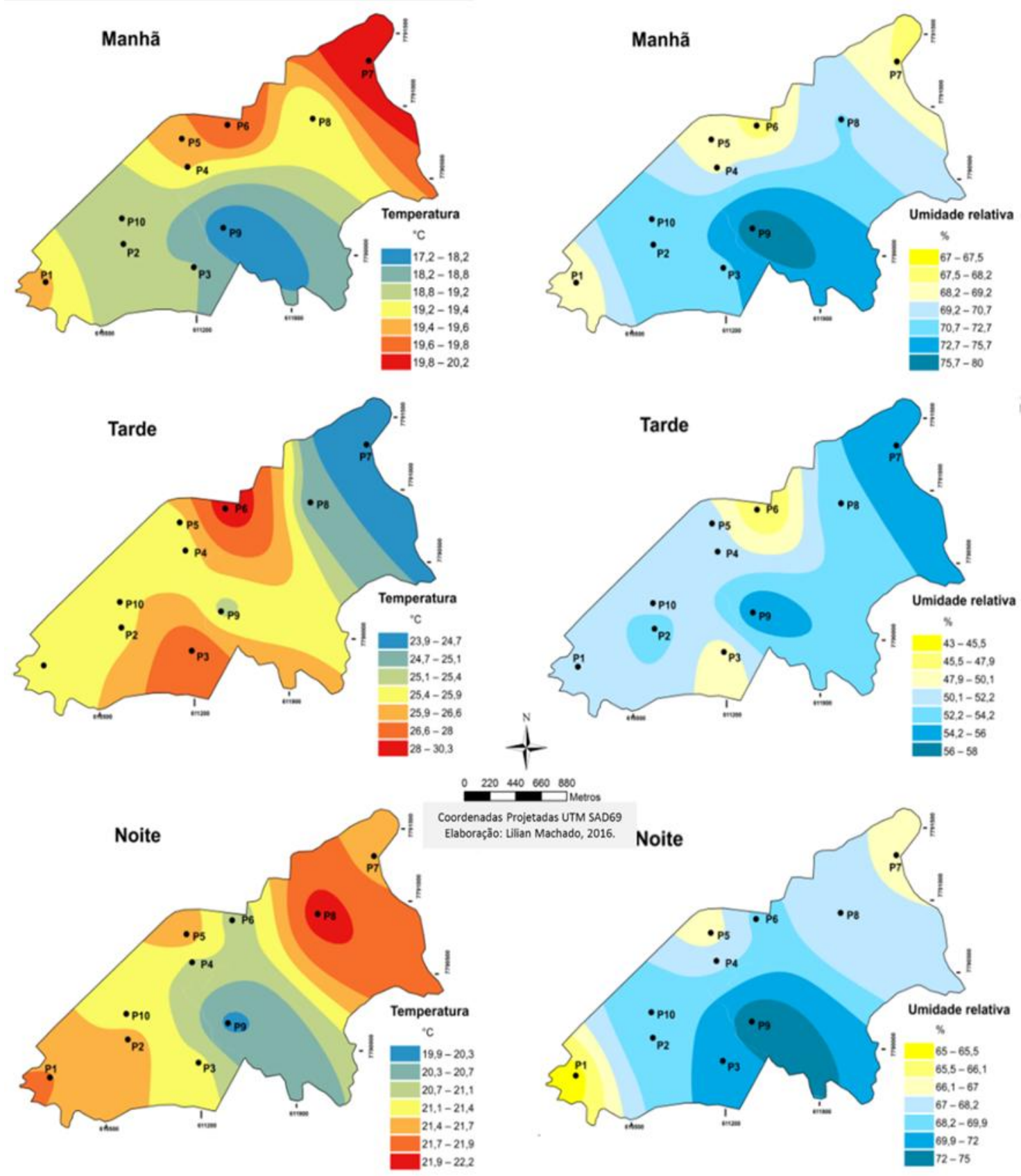

220440600800
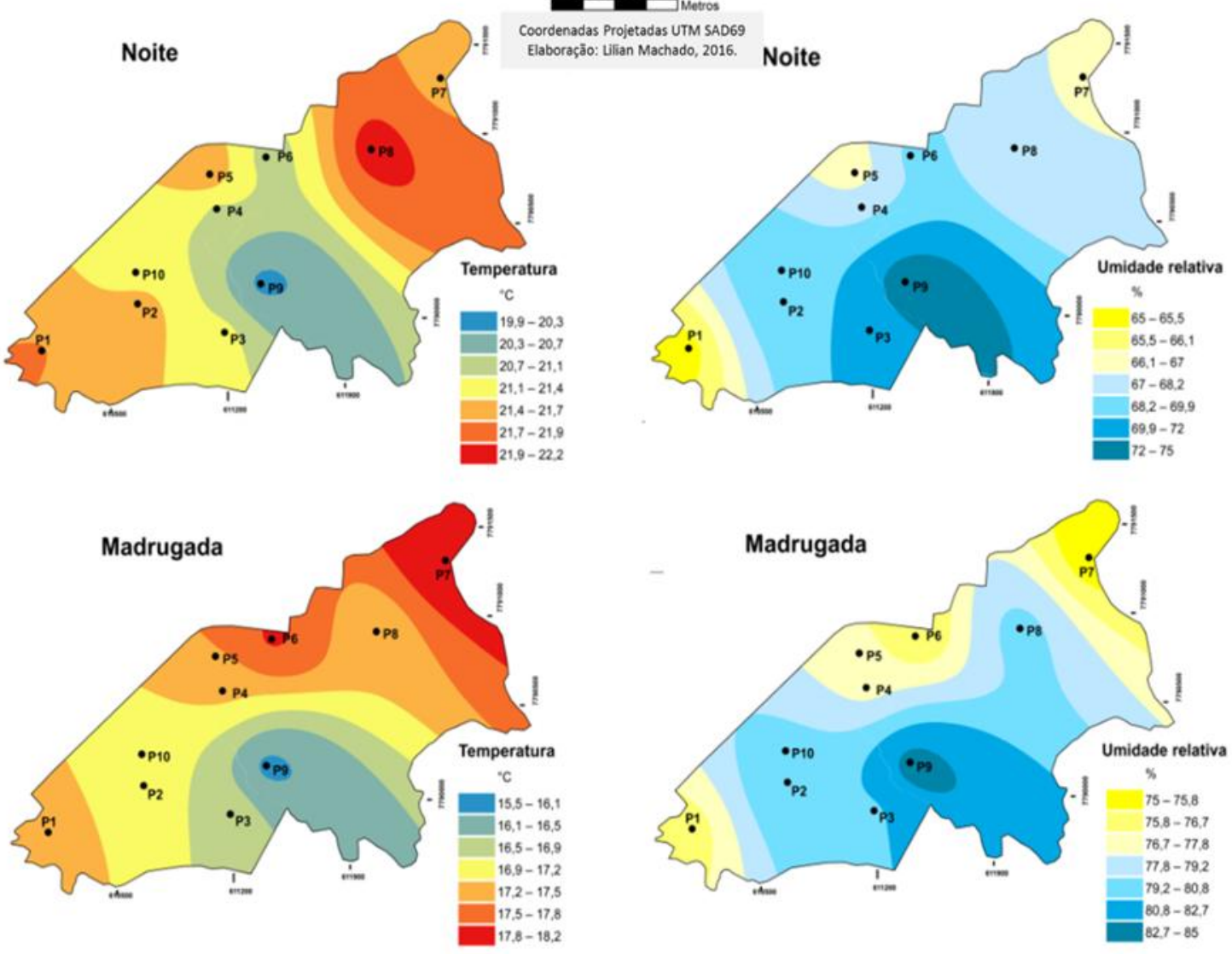

Figura 11: Comportamento térmico e hígrico por período - Campo. 


\section{Obstrução da abóbada celeste}
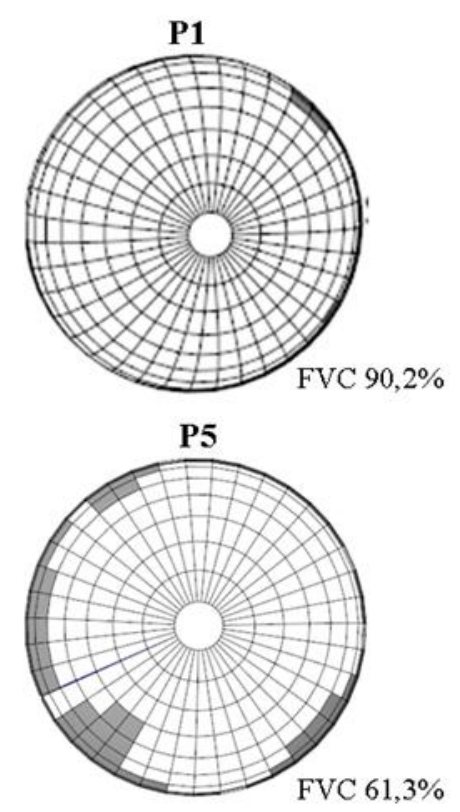

P8

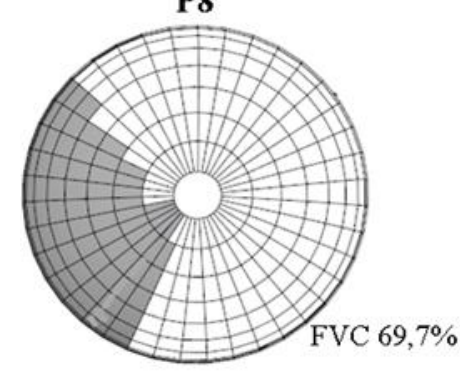

P3

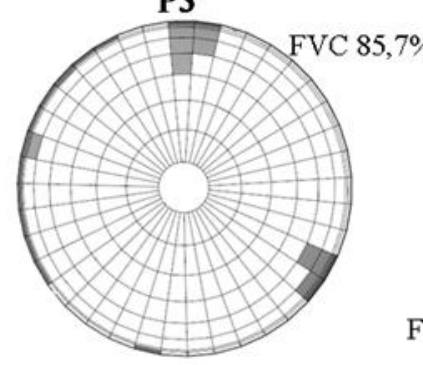

P6

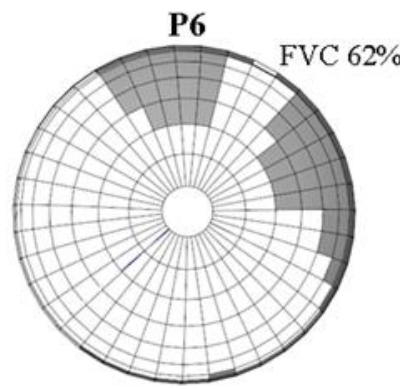

P10

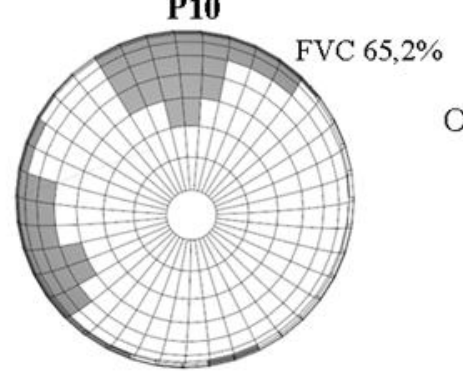

P4
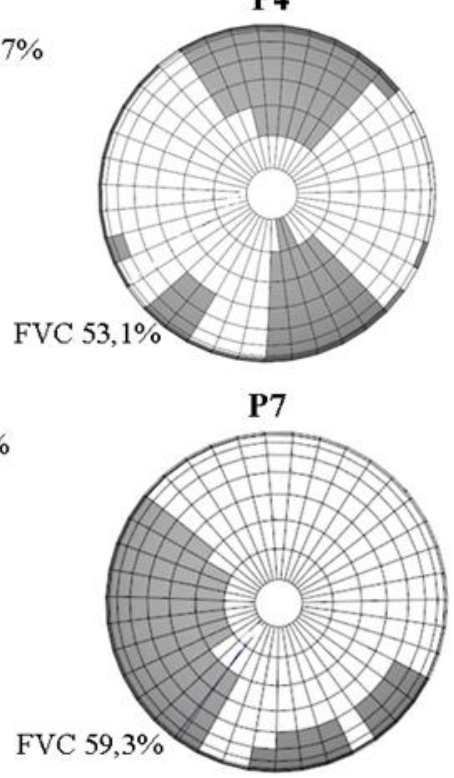

FVC $59,3 \%$

Os Pontos 2 e 9 localizam-se sob dossel arbóreo e, portanto, não recebem iluminação solar direta, sendo seu FVC mínimo.

Figura 12: Fator de Visão do Céu por ponto amostral. Elaboração: Lilian Machado, 2016.

\section{CONCLUSÕES}

A motivação para a elaboração deste trabalho surgiu da preocupação com o padrão de avanço urbano na área limítrofe entre os municípios de Belo Horizonte e Nova Lima, nos bairros Vila da Serra, Vale do Sereno, Piemonte, Jardinaves e Jardim das Mangabeiras. O principal objetivo da pesquisa foi diagnosticar as respostas térmica, hígrica e anemométrica frente às características geoecológicas e de ocupação urbana dos bairros, em escala micro e topoclimática.

Foi observado que a nível micro e topoclimático, o comportamento atmosférico está intimamente atrelada às características geoecológicas e ao padrão de ocupação urbana da região. A resposta atmosférica nesses níveis, no entanto, é mutável conforme se alternam os sistemas sinóticos. A atuação do Anticiclone Subtropical do Atlântico Sul (ASAS), o qual permaneceu sobre o continente durante a maior parte dos experimentos de campo, permitiu amplitudes térmicas pronunciadas entre os locais de arranjos geoecológicos distintos na área de estudo. Sob atuação de sistemas instáveis, como as Linhas de Instabilidade (LI) e Frentes Frias (FF), as temperaturas variaram pouco entre os pontos amostrais, com diferença média de $1,4^{\circ} \mathrm{C}$ entre o local mais frio e o mais aquecido. A mesma resposta se obteve sob a permanência do Anticiclone Subpolar do Atlântico Sul (APAS), embora as médias de temperatura do ar nesse caso tenham sido as mais baixas, entre $15^{\circ} \mathrm{C}$ e $16^{\circ} \mathrm{C}$.

Observou-se que, sob atuação predominante do ASAS, as áreas urbanas de maior altitude são as mais aquecidas, já que estão, em sua maior parte, voltadas para norte, favorecendo o aquecimento no ambiente urbano. Portanto, neste caso, a orientação das vertentes supera o efeito atenuador esperado da altitude sobre o ambiente urbano, provocando núcleos de aquecimento nas áreas de topo ocupadas por edifícios. Nestes locais, durante a noite, a altitude e a condição de topo torna o ar mais aquecido em relação às áreas rebaixadas devido ao transporte do ar frio para os fundos de vale. Concomitantemente, a proximidade dos edifícios favorece a perda lenta da temperatura, em função da diminuição do Fator de Visão do Céu (FVC), 
tornando os topos mais aquecidos durante a noite. Assim, a verticalização em áreas de topo pode potencializar o aquecimento local durante o dia e a noite.

Por outro lado, a conformação do relevo na área de estudo favoreceu a atenuação das temperaturas nos fundos de vale e vertentes voltadas para o quadrante sul. Nestes locais, onda há ocupação urbana, esta é composta por edificações unifamiliares que não interferem no comportamento atmosférico de maneira suficiente para gerar um topoclima urbano.

As áreas mais adensadas e impermeabilizadas apresentaram menores índices médios de umidade do ar. Em contrapartida, sobre vertentes voltadas para norte e ocupadas por campo cerrado com urbanização incipiente, a iluminação solar direta no período da tarde eleva as temperaturas e reduz a umidade do ar em níveis semelhantes às áreas densamente urbanizadas, como ocorreu no entorno do P3. Neste local, o adensamento urbano poderia potencializar o núcleo de calor já observado. Já nos perímetros urbanos de baixa ocupação e lotes bem arborizados, os elementos urbanos influenciam pouco a dinâmica hígrica atmosférica. Nessas áreas, a cobertura vegetal arbórea favorece temperaturas mais amenas e maior umidificação do ar.

Ficou claro que o relevo ocupa uma função primária nas características topoclimáticas da área de estudo, uma vez que a orientação das vertentes interfere na distribuição da radiação solar na superfície, determinando a resposta térmica diurna, enquanto a altitude, junto aos atributos de geomorfologia que configuram no período noturno a circulação catabática, influenciam na distribuição de calor na superfície no período noturno. Em experimentos realizados na Serra do Souza por Machado (2013), e na Serra do Cipó por Machado et al. (2014), ambas em Minas Gerais, e no vale do rio Barcarena por Lopes (1995), em Portugal, foi observada a mesma relação entre relevos de topo e a manutenção de calor na atmosfera nesses locais no período noturno, em comparação com os fundos de vale. Assim, seria preferível manter livres de ocupação urbana verticalizada estes ambientes na área de estudo.

A cobertura vegetal e as características de ocupação urbana distinguem as intensidades de aquecimento ou resfriamento atmosférico. As áreas de fundo de vale, de altitude reduzida, são sombreadas durante parte do dia, o que as torna mais amenas do que os locais de altitude elevada. A predominância de vegetação de porte arbóreo nesses espaços potencializa o efeito topográfico, tornando-as as áreas mais frescas na região. Da mesma forma, a ocupação urbana densa e verticalizada em áreas de topo intensifica o aquecimento atmosférico, já favorecido pela condição topográfica desses locais. Nas áreas mais adensadas e verticalizadas foram observadas as maiores temperaturas mínimas do ar. Esse efeito é produzido pelas características urbanas no entorno, assim como observou Assis (2010) em Belo Horizonte.

No que diz respeito à influência das áreas arborizadas sobre a temperatura do ar abaixo da camada do dossel, esperava-se observar um efeito térmico atenuador durante o dia e a retenção de calor sob o dossel ao longo da noite, conforme apontaram os estudos de Oke (1978), Baumüller et al. (1997), Machado et al. (2014). Durante o dia, foi observada a atenuação térmica sob a camada de dossel. Porém, a superfície arborizada está concentrada no entorno de talvegues nos fundos de vale e nas áreas mais rebaixadas do relevo, destino para o qual flui o ar resfriado e denso que desce as encostas durante a noite. Logo, o ar frio transportado pelos ventos catabáticos se acumula nesses locais, tornando-os mais frios que os demais no período noturno.

\section{REFERÊNCIAS}

ASSIS, W. L. O sistema clima urbano do município de Belo Horizonte na perspectiva têmporoespacial. 2010, 299 f. Tese (Doutorado em Geografia) - Instituto de Geociências, Universidade Federal de Minas Gerais, 2010.

BAUMÜLlER, J; HOFFMAN, U; REUTER, U. Cartilha urbanística do clima - Sequência 2. Tradução de Francisco Assis Gonçalves da Silva. Paraíba: Universidade Federal da Paraíba, 1997. 194p.

BIAS, E. S.; BAPTISTA, G. M. M.; LOMBARDO, M. A. Análise do fenômeno de ilhas de calor urbanas, por meio da combinação de dados Landsat e Ikonos. In: XI Simpósio Brasileiro de Sensoriamento Remoto, 2003, Belo Horizonte. Anais..., Belo Horizonte, 2003. p. 1741-1748.

CRAVEIRO, C. A produção do espaço do espaço das Seis Pistas como nova centralidade periférica no espaço metropolitano Belo-Horizontino. Caderno de Geografia, Belo Horizonte, v. 15, n. 24, p. 68-77, 2005. 
CENTRO DE PREVISÃO DE TEMPO E ESTUDOS CLIMÁTICOS. Monitoramento EI Niño - Oscilação Sul. CPTEC, setembro 2015. Disponível em: < http://enos.cptec.inpe.br/>. Acesso em: novembro de 2015.

DUARTE, D. H. S.; SERRA, G. G. Padrões de ocupação do solo e microclimas urbanos na região de clima tropical continental brasileira: correlações e proposta de um indicador. Ambiente Construído, Porto Alegre, v. 3, n. 2, p. 7-20, abr./jun. 2003.

LANDSBERG, H. E. O clima das cidades. Revista do Departamento de Geografia da USP, São Paulo, n. 18, p. 95-111, 2006.

MACHADO, L. A. Implicações da verticalização dos bairros Vila da Serra e Vale do Sereno (Nova Lima, MG) na circulação atmosférica local. 2013, 144f. Monografia (Bacharelado em Geografia), Universidade Federal de Minas Gerais, 2013.

MACHADO, L. A.; GONCALVES, I.; MAGALHAES, M. A. N.; ASSIS, W. L. Análise do comportamento térmico e hígrico em área do Parque Nacional da Serra do Cipó. In: XI Simpósio Brasileiro de Climatologia Geográfica, 2014, Curitiba. Anais...Curitiba: UFPR, 2014, v. 1. p. 449-460.

MENEGALE, M. B. C. S. A transformação territorial de um município de tradição mineradora: estudo de caso sobre a recente ocupação do norte de Nova Lima, circundante à Mata do Jambreiro. 2002. 164 f. Dissertação (Mestrado em Arquitetura e Urbanismo) - Universidade Federal de Minas Gerais, 2002.

MONTEIRO, C. A. F. Análise rítmica em climatologia; problemas da atualidade climática em São Paulo e achegas para um programa de trabalho. Série Climatologia Dinâmica I, São Paulo, 21p, 1971.

MONTEIRO, C. A. F. Teoria e clima urbano. São Paulo: IG06-USP, 1976. 181p.

MONTEIRO, C. A. F. A cidade como processo derivador ambiental e a geração de um clima urbano Estratégias na abordagem geográfica. GEOSUL, Florianópolis, v. 5, nº 9, p. 80-114, 1990.

NUNEZ, M; OKE, T. R. The energy balance of an urban canyon. Applied Meteorology, v. 16, p. 11-19, 1977.

OKE, T. R. Boundary layer climates. London: Methuem e Co. LTD, 1978. 372p.

ROMERO, M. A. B. Princípios Bioclimáticos para o desenho urbano. São Paulo: Copy Market, 2000. $63 \mathrm{p}$. 